\title{
ВЛИЯНИЕ БОЛЬШИХ ДОБАВОК СОЛИ НА ВЭЖХ РАЗДЕЛЕНИЕ ГОМОЛОГОВ
} Томилова Е.В., Новиков Д.В.

Национальный исследовательский Томский государственный университет, Томск, Россия eminencegrisemstrp@gmail.com

DOI: $10.26902 / A S F E-11 \_49$

Задача ВЭЖХ-разделения гомологов органических веществ, как известно, успешно решается использованием выскокоуглеродистых стационарных фаз, имеющих высокую селективность по отношению к веществам, отличающимся на один и более атомов углерода. Однако, такие задачи, как, например, разделение родственных примесей в фармацевтическом анализе требует, как правило, более сложных типов селективности, чем классическая обращенная фаза на $\mathrm{C}_{18}$-сорбентах. Одним из примеров может служить метод разделения родственных примесей в препарате «Аденурик» (действующее вещество - фебуксостат). По своей структуре примеси фебуксостата представляют собой гетероароматические и ароматические системы с полярными ионными и неионизирующимися заместителями. Добиться разделения на стационарной фазе $\mathrm{C}_{18}$-сорбенте, как было установлено, невозможно, однако, при замене его на более низкоуглеродистый сорбент $\mathrm{C}_{8}$ появляется возможность увеличения селективности к веществам с одинаковым количеством углерода, но разным типом полярных заместителей.

Такая замена приводит к падению разрешения между примесями гомологами. Было установлено, что одним из способов тонкой настройки селективности между веществами гомологами в условиях смешанного режима (обращенно-фазовый и ионный) является добавление больших количеств соли (более 50 ммоль). Одной из вероятных причин является высаливающий эффект соли и хаотропный эффект. Увеличение разрешения происходит только счет увеличения селективности, а не за счет эффективности и удерживания. При этом, разрешение между молекулами остальных примесей и основным веществом не изменяется. На рис. 1 представлены результирующие хроматограммы, подтверждающие вышеуказанные утверждения.

Разработанная методика удовлетворяет всем валидационных критериям согласно требованиям ICH [1] и внедрена на площадку производителя препарата. Стот отметить, что в литературе не было найдено методик анализа, позволяющих контролировать качество препарата «Аденурик» по показателю «Родственные примеси» с удовлетворительным результатом.
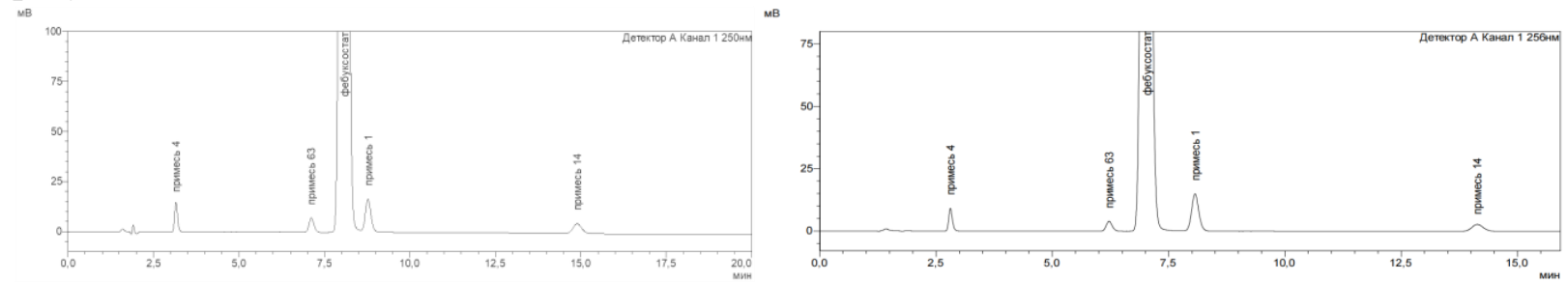

Рисунок 1 - Влияние добавки соли на разрешение между критической парой: a) хроматограмма тестовой смеси при 30 ммоль буфера в подвижной фазе (Rs между пиком фебуксостата и примесью $1=1,5)$; б) хроматограмма тестовой смеси при 80 ммоль буфера в подвижной фазе $\left(\mathrm{R}_{\mathrm{S}}\right.$ между пиком фебуксостата и примесью $\left.1=3,1\right)$

\section{Список литературы}

1. ICH Topic Q3B (R2) Impurities in new drug products CPMP/ICH/2738/99. - 2006. 